\title{
Ways to Help and Ways to Hinder: Governance for Effective Adaptation to an Uncertain Climate PHILIP A. LORING, ${ }^{1,2}$ S. CRAIG GERLACH, ${ }^{1}$ DAVID E. ATKINSON ${ }^{3}$ and MARIBETH S. MURRAY4
}

\author{
(Received 16 February 2010; accepted in revised form 29 June 2010)
}

\begin{abstract}
This paper compares two case studies in Alaska, one on commercial fishers of the Bering Sea and Aleutian Islands region and the other on moose hunters of Interior Alaska, to identify how governance arrangements and management strategies enhance or limit people's ability to respond effectively to changing climatic and environmental conditions. The two groups face similar challenges regarding the impacts of a changing climate on wild fish and game, but they tell very different stories regarding how and under what conditions these impacts challenge their harvest activities. In both regions, people describe dramatic changes in weather, land, and seascape conditions, and distributions of fish and game. A key finding is that the "command-and-control" model of governance in the Alaska Interior, as implemented through state and federal management tools such as registration hunts and short open seasons, limits effective local responses to environmental conditions, while the more decentralized model of governance created by the Limited Access Privilege systems of the Bering Sea allows fishers great flexibility to respond. We discuss ways to implement aspects of a decentralized decision-making model in the Interior that would benefit hunters by increasing their adaptability and success, while also improving conservation outcomes. Our findings also demonstrate the usefulness of the diagnostic framework employed here for facilitating comparative crossregional analyses of natural resource use and management.
\end{abstract}

Key words: fisheries management, wildlife management, adaptation, adaptive significance, environmental policy, subsistence, co-management

RÉSUMÉ. Ce document établit une comparaison entre deux études de cas effectuées en Alaska, l'une portant sur les pêcheurs commerciaux de la mer de Béring et de la région des Aléoutiennes et l'autre, sur les chasseurs d'orignaux de l'intérieur de l'Alaska. Cette comparaison avait pour but de déterminer comment les ententes de gouvernance et les stratégies de gestion rehaussent ou restreignent l'aptitude des gens à réagir de manière efficace au changement climatique et aux conditions environnementales. Dans le cas des deux groupes, les défis sont semblables en ce qui a trait aux incidences du changement climatique sur le poisson sauvage et le gibier, mais il n'en reste pas moins que les deux groupes témoignent d'histoires très différentes relativement à la façon dont les incidences influencent leurs activités de chasse ou de pêche, et les circonstances dans lesquelles les incidences présentent des défis à leurs activités de chasse ou de pêche. Dans les deux cas, les individus décrivent des changements dramatiques sur le plan des conditions météorologiques, du paysage terrestre et du paysage marin, ainsi que sur le plan de la répartition du poisson et du gibier. Une des grandes observations ayant émané de cette comparaison, c'est que le modèle de gouvernance consistant à « commander et contrôler » qui est en vigueur dans l'intérieur de l'Alaska, tel qu'imposé par les outils de gestion de l'État et du gouvernement fédéral, et qui se traduit notamment par l'enregistrement des chasses et par des saisons de chasse courtes, se trouve à restreindre l'efficacité des réactions locales vis-à-vis des conditions environnementales, tandis que le mode de gouvernance plus décentralisé créé par les systèmes de privilège à accès limité de la mer de Béring donne aux pêcheurs une plus grande souplesse pour réagir. Nous nous penchons sur diverses façons de mettre en œuvre les aspects d'un modèle de prise de décisions décentralisé dans l'intérieur de manière à ce que les chasseurs en bénéficient en augmentant leur adaptabilité et leur succès, tout en améliorant les résultats de conservation. Nos constatations démontrent aussi l'utilité du cadre diagnostic employé ici pour faciliter les analyses inter-régionales en matière d'utilisation et de gestion des ressources naturelles.

Mots clés : gestion des pêches, gestion de la faune, adaptation, importance adaptative, politique environnementale, subsistance, cogestion

Traduit pour la revue Arctic par Nicole Giguère.

\footnotetext{
${ }^{1}$ Center for Cross-Cultural Studies, University of Alaska Fairbanks, PO Box 756730, Fairbanks, Alaska 99775, USA

${ }^{2}$ Corresponding author: ploring@alaska.edu

${ }^{3}$ Department of Atmospheric Sciences, University of Alaska Fairbanks, PO Box 757320, Fairbanks, Alaska 99775, USA; present address: Department of Geography, University of Victoria, PO Box 3060 STN CSC, Victoria, British Columbia V8W 3R4, Canada

${ }^{4}$ Department of Anthropology, International Arctic Research Center, University of Alaska Fairbanks, PO Box 767730, Fairbanks, Alaska 99775, USA

(C) The Arctic Institute of North America
} 


\section{INTRODUCTION}

Late summer and early fall of 2007 in Interior Alaska saw a lot of rain. Too much, really, which among other problems proved to be quite the challenge for those of us looking for moose in the Minto Flats. One time in particular, I was out on the water with my friend Patrick Smith, then the second tribal chief of the village of Minto. We were heading back after a long and unsuccessful day of searching all his customary spots. The weather had turned rainy and cold, the visibility was poor, and the water just too high. On the trip home, we encountered another hunting party from Minto, three younger men, each standing waist-deep in the muck and trying, in vain, to pull a bull moose they had shot out of the water and up onto the bank. They had timed their shot for just as the moose jumped out of the water, normally the right thing to do. But with the high water and wet conditions, the downed bull had slipped down the muddy bank. When we found them, the moose was under nearly three feet of water, and the men were shivering and waterlogged, their lips blue with cold. It took the five of us another two hours to get that 1500-pound beast onto dry ground, where it could finally be gutted and packed on their skiff. We very nearly lost it, and that would have meant losing a winter's worth of meat for two families at least.

Adapted from the field notes of Philip A. Loring

Subsistence hunting and fishing play a central role in the economic and environmental security and sustainability of communities in Alaska and elsewhere in the circumpolar North (Holthaus, 2008; Ford, 2009; Loring and Gerlach, 2009), provided that weather and environmental conditions are favorable and people have access to the land and sufficient fuel, supplies, time, and expertise. However, events like those related in the vignette above are increasingly common in Alaska and elsewhere in the North, with the caveat that they do not always share such a fortunate ending. The climate and ecosystems of the North are changing (Krupnik and Jolly, 2002; ACIA, 2005), and livelihoods based on Alaska's landscapes and seascapes are increasingly constrained. Constraints are variability in daily and seasonal environmental conditions, a patchwork of land tenure, and complicated and sometimes conflicting resource management regimes that are not designed to keep pace with current and predicted rates of environmental variability and change (McNeeley, 2009; Loring, 2010). Many parts of the Arctic are now experiencing oil, mineral, and natural gas exploration and rising food and fuel prices in an uncertain global economy. In the midst of these conditions, the impacts of a changing environment only aggravate the situation of systems already under significant stress (Lynch and Brunner, 2007; Fazzino and Loring, 2009).

However, while many communities in the North are experiencing these challenges in a context of vulnerability and environmental insecurity (Alessa et al., 2008; Ford,
2009; Egeland et al., 2010), others are finding ways to respond effectively to changes in their environment (Keskitalo, 2008; Forbes et al., 2009). A crucial task in human adaptation research, therefore, is to move beyond individual ethnographies and case studies to a mode of comparative analysis that can examine and explain such differences and guide the creation of effective, place-based responses to environmental challenges (Ostrom, 2007; Loring et al., 2008). Adaptation, as broadly writ, does not necessarily guarantee a particular outcome, desirable or otherwise (Mayr, 1982:49-51; Bennett, 1996:31), though this is frequently the implication of the term as used in the sustainability literature (e.g., Walker et al., 2004; Chapin et al., 2006; Ford, 2008). There remains a need to identify and understand adaptations and adaptability in terms of "adaptive significance" (Mazess, 1975) — why some communities can respond to change in ways that maintain and even improve their health and environmental security (i.e., adaptation in the context of sustainable design), while others are "locked in" to less effective and less sustainable responses (Allison and Hobbs, 2004).

Since 2005, we have been engaged in a project designed to compare the impacts of regional environmental change on food security for a number of rural Alaska communities on the Tanana and Yukon rivers. As part of a separate project, we visited a group of Alaska coastal communities in 2008 to assess local needs for institutional support (e.g., weather and storm advisories and forecasts, unaddressed research questions). During these visits, we identified an opportunity for comparison between coastal livelihoods, based primarily on commercial fishing in the Bering Sea and Aleutian Islands (BSAI) region, and subsistence livelihoods of the Alaska Interior.

In this paper we report the results of needs-assessment interviews conducted in both regions and employ an ecosystem services-based framework (c.f. Loring et al., 2008) to diagnose the mechanisms by which governance arrangements in each case serve to help or hinder people trying to respond effectively to new and changing ecological constraints. People in the two regions reported similar encounters with changes to the landscape and seascape that match other accounts of and projections for climate change in the North (e.g., Krupnik and Jolly, 2002; ACIA, 2005). People shared with us the challenging decisions they must make daily and seasonally in order to maintain successful livelihoods based on the procurement of wild fish and game. However, while people in the Interior repeatedly discussed how policies such as regulated hunting and fishing seasons exacerbate the difficulties brought by climate change, people on the coast described how recent changes in fisheries policy can improve their ability to adapt effectively to changing conditions, improving their economic security and lessening some of the dangers their "deadliest catch" lifestyle is now known for.

This comparative exercise reveals options based on examples from the coast for improving outcomes in the Interior, fundamentally by replacing the current, top-down 
governance regime with one that facilitates a more decentralized approach to co-management (c.f., Pinto da Silva and Kitts, 2006). The exact form that co-management may take in the Interior must emerge largely via experimentation and innovation by hunters testing different forms of group self-organization and through negotiation between hunters and management authorities regarding the redistribution of power and trust (Pinto da Silva and Kitts, 2006; Kofinas et al., 2007). Still, specific principles for designing governance structures that facilitate effective responses to environmental variability are gleaned from the perceived strengths and weaknesses of both cases. These include coupling hunting privilege with management responsibilities and creating mechanisms to increase informational support to users in terms of weather, forecasting, and research. While our discussion of these aspects of governance and adaptation is keyed to the specifics of two regional Arctic systems, the recommendations we highlight should have analogues relevant to pan-Arctic co-management challenges.

\section{KEY CONCEPTS}

This paper is about adaptation and the role that governance plays in facilitating the design of effective, sustainable responses to environmental variability and change. The concept of "adaptation" is widely used in the biological and social sciences, and more recently, it has been borrowed into the sustainability sciences. However this term, while used extensively, is not always used consistently. As we use it here (in specific reference to human dimensions), adaptation refers to coping mechanisms that humans employ in obtaining wants and needs and in adjusting their lives to the surrounding socionatural milieu (Mazess, 1975; Bennett, 1976:246; Moran, 1981). The related concept of "adaptability" refers to the flexibility and resources that a person or community has or can use to design and implement adaptations (Moran, 1979). Adaptation has both causal and anticipatory aspects, meaning that people adapt to their social and natural environs, to the extent they are able to do so (their adaptability), in ways that involve forethought and innovation (Bennett, 1996:28-29). This separates the concept of adaptation from mitigation, as mitigation implies reactive responses, usually short-term, to the impacts of circumstances considered non-normal, such as in the context of disaster (Glantz, 2001; Pomeroy et al., 2006; EPA, 2009).

As noted, adaptation neither guarantees nor implies a particular outcome (e.g., sustainability or resilience), though the term is regularly used in this way (e.g., Walker et al., 2004; Chapin et al., 2006; Ford, 2008). For instance, Ford (2008:8) suggests that "adaptation policy can bring immediate benefits in the form of reduced sensitivity to climatic risks." As Bennett (1996:31) explains, however, "such directional relationships...must be treated as empirical possibilities, not as natural laws." Adaptations are simply behaviors inclined toward one's environment; evaluating the outcome of an adaptation, that is, its adaptive significance (c.f.,
Mazess, 1975), requires the introduction of a judgmental dimension - a set of values regarding specific outcomes at specific spatial and temporal scales (Bennett, 1976:298$300)$. In this paper, when we discuss the ability of a person or a community to adapt, we ascribe adaptive significance to those responses to change that maintain or improve individual and community health and environmental security as an integrated and sustainable outcome (Costanza et al., 2007).

Governance, the second primary concept in this discussion, describes the arrangement of power in a social system, often relating to the management of natural resources (Deitz et al., 2003). Governance plays a significant part in determining individual and community adaptability (Armitage et al., 2007). Generally speaking, governance is a system of roles for resource managers and resource users, regarding who has authority to make management decisions (and at what scale) and who is accountable (Goetz, 2004; Pomeroy and Rivera-Guieb, 2005:33-42). In the context of environmental change, the design of these roles influences both the manner and the effectiveness of responses (Young, 2002). "Co-management," for instance, describes a paradigm of governance whereby natural resource management authority is shared or distributed among multiple sets of stakeholders, usually between some at the state level and some at the community level (Pomeroy and Berkes, 1997; Armitage et al., 2007). The operating hypothesis for the co-management paradigm is that adaptability is increased by involving multiple sets of stakeholders in management roles that can change and evolve in response to environmental variability (Kofinas et al., 2007; Armitage et al., 2009). The intent of this paper is to build upon this premise, by providing the detail necessary to support not just adaptability in the most generic sense, but effective, place-based responses to change in a context of community health and sustainable design (Guyette, 1996).

\section{METHODS}

Two cases are compared in detail: subsistence moose hunting in Interior Alaska and commercial ground-fish fishing in the BSAI region (Fig. 1). The needs assessment process involved one-on-one interviews and informal, round-table discussions in the communities of Minto (population 190), Fort Yukon (population 587), and Unalaska (population 3551; also referred to by the nickname "Dutch Harbor," after the name of the harbor itself) (Alaska Department of Commerce, Community, and Economic Development, 2007), completed in the summers of 2008 and 2009. There was no direct compensation for participation. In total, we interviewed 38 people, 23 in Unalaska (representing the coastal, commercial fishing system), and 10 in Fort Yukon and 5 in Minto (representing the subsistence hunting system), all of whom speak English. Sample size can be a challenge in remote Alaska, as residents commonly travel away from the village to hunt, fish, and trap, or for wage 


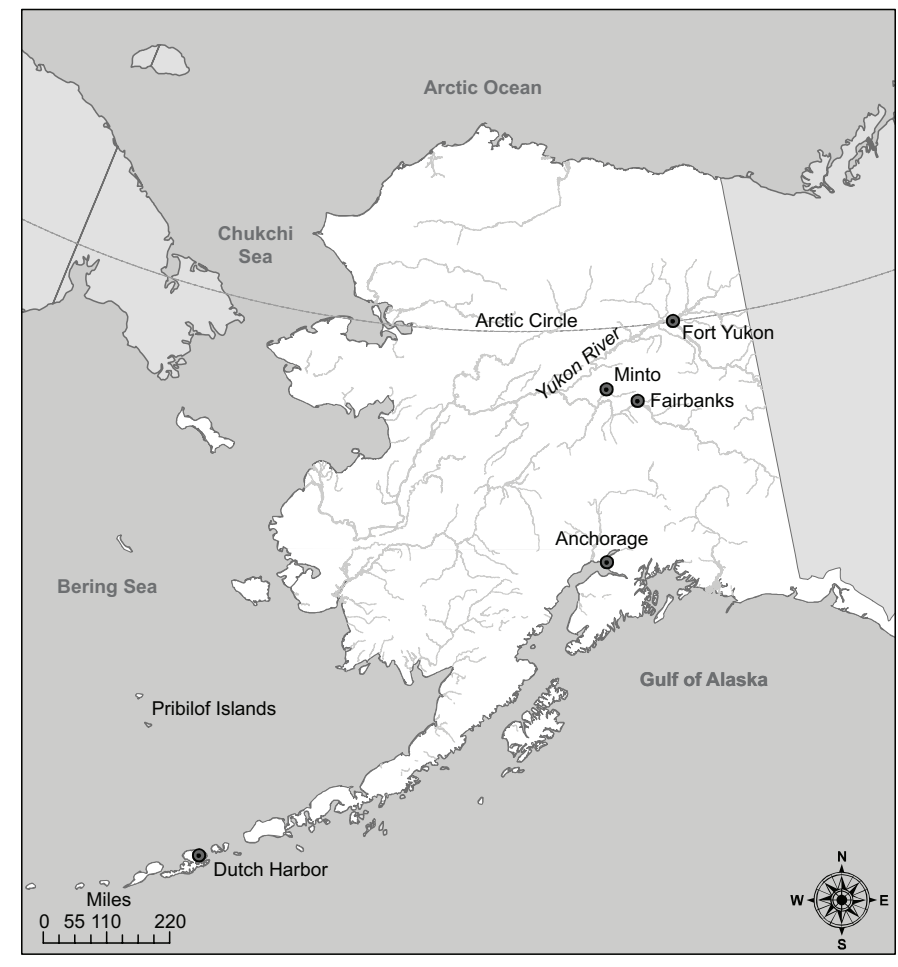

FIG. 1. Map of Alaska showing the study locations and other geographic reference points discussed. Map by Nicole Dufour, Department of Anthropology, University of Alaska Fairbanks.

jobs, and the cost of repeated flights to villages can be prohibitive. Local leaders (e.g., tribal council members, harbormaster) helped us to select knowledgeable individuals, and we scheduled our visits to each village so as to maximize the participation of these key informants. We then used the "snowball method" to identify more informants, asking the first group of interviewees to recommend additional participants from those in the village at the time. The majority of the participants ( 30 of 38 ) were men, reflecting the general demographics and division of labor in the region (Hamilton and Seyfrit, 1994; Goldsmith, 2008).

Participants were asked to describe the challenges they face in trying to make a successful harvest. Each interview began with the same non-leading, open-ended questions about harvest success: "Has it been a good or bad year for hunting and fishing?" and, "What would you say have been the best opportunities and the biggest challenges?" These were followed by more targeted questions designed to identify concerns about weather conditions, access and availability of wild fish and game, the roles of policy and policy enforcement, and issues of personal safety. There was no time limit on the interviews.

A standard set of concepts and terms is essential for effective comparative social analysis (de Groot et al., 2002; Ostrom, 2009). Therefore, follow-up questions (and subsequent analysis) were based on the Services Oriented Architecture (SOA) framework designed by Loring et al. (2008), which provides a common descriptive language for assessing and comparing the uses of ecosystem services in different groups or communities. The SOA is rooted in path dependence-path creation (PDPC) theory (c.f., Garud and Karnøe, 2001), which is compatible with the definition of human adaptation provided under Key Concepts above. PDPC situates human actions within social and ecological contexts, but also attributes to people a capacity to reflect and innovate - to take actions outside the prescriptions of social rules and historical artifacts. PDPC theory describes people as "mindful entrepreneurs" who "meaningfully navigate a flow of events" (Garud and Karnøe, 2001:2).

Central to the SOA is the concept of viability: whether or not an ecosystem service is a practical option for a particular group of users, and how those users respond to a mix of ecological, social, and political drivers and determinants, including weather, ecological changes, social, cultural, and economic policies (see Table 1 for an overview of the framework). If opportunities for using the ecosystem service are broad, people tend to have more room to adapt effectively to changing constraints; likewise, if constraints make opportunities for ecosystem service use very specific in space or time, people can be more vulnerable to variability and change.

After interviewing the local residents, we also conducted formal and informal interviews with state wildlife biologists and agency managers from the Alaska Department of Fish and Game, the U.S. Fish and Wildlife Service, and the Harbormaster's Office in Unalaska. The primary goal was to improve our understanding of management regimes and processes, including roles, responsibilities, and challenges at the agency level.

To help with the analysis of interview transcripts, we used Verity K2 software by Verity, Inc. to identify common key words and phrases, which we then organized manually within the thematic headers provided by the SOA (ecological constraints, policy, contract, compatibility, awareness, willingness) to create a data dictionary. The data dictionary was then used through the software to index the transcripts by theme.

\section{CASE 1: MOOSE-HUNTING VIABILITY IN THE YUKON CIRCLE}

For millennia, Alaska Natives living in Interior Alaska, which generally includes the upper Yukon and Tanana River flats regions, have subsisted on a diverse array of wild, country foods. Salmon (Oncorhynchus spp.) and ungulates such as moose (Alces alces) and caribou (Rangifer taran$d u s$ ) are the primary wild food sources, but a variety of other fresh and saltwater fish, migratory waterfowl, traditional root-crop gardens, and berries and other wild botanical resources are also important (Wolfe, 2004; Loring and Gerlach, 2010). Food from the store, either purchased from the small local stores or shipped home during trips to urban centers, also plays an important part in the regional food system (Wheeler, 1998; Fazzino and Loring, 2009).

Moose hunting generally involves travel up and down a river by boat or across dry land by all-terrain vehicle (ATV). 
TABLE 1. Concepts of the services-oriented architecture, with example questions.

\begin{tabular}{|c|c|c|}
\hline Core viability factors & Description & Example questions \\
\hline Reachability & $\begin{array}{l}\text { The practicality of access to a resource. Determined by: } \\
\text { - ecological constraints (e.g., climate, land-cover) } \\
\text { - social impositions (e.g., policies and contracts) } \\
\text { - financial constraints (e.g., energy costs, purchase and maintenance } \\
\text { costs of technologies needed for successful harvest and use) } \\
\\
\text { How policies and contracts vary across stakeholder groups speaks to } \\
\text { matters such as differential distribution of access to resources (equity } \\
\text { and justice). }\end{array}$ & $\begin{array}{l}\text { - You said you needed to take more time or travel } \\
\text { farther to find a moose. Why is this a problem? } \\
\text { - What are the primary reasons for a failed hunt? }\end{array}$ \\
\hline Compatibility & $\begin{array}{l}\text { Whether the resource is usable by the consumer. This includes: } \\
\text { - safety and quality of the resource itself } \\
\text { - available methods of harvest/procurement } \\
\text { mether or not the user has the resources and skills to perform those }\end{array}$ & $\begin{array}{l}\text { - You mentioned that storms can mix larger and } \\
\text { smaller fish. Why is this a problem? } \\
\text { Are there reasons you might not be able to use a } \\
\text { moose even if you catch it? }\end{array}$ \\
\hline Awareness & $\begin{array}{l}\text { The knowledge of the resource, such as: } \\
\text { - skill required to access and harvest the resource (e.g., when and where } \\
\text { to hunt or fish) } \\
\text { - an understanding of any risks associated with use (e.g., contamination) } \\
\\
\text { If environmental conditions change, awareness can be compromised. } \\
\text { Whether or not a user has accurate and timely information is crucial, } \\
\text { and when viewed across stakeholder groups, can reflect inequities } \\
\text { manifest in the distribution and availability of information. }\end{array}$ & $\begin{array}{l}\text { - What sorts of tools or methods do you use to find } \\
\text { fish? } \\
\text { What information do you use to choose where to } \\
\text { hunt, and how do you use it? }\end{array}$ \\
\hline Willingness & $\begin{array}{l}\text { - accepting of any risks or uncertainties related to harvest } \\
\text { requisite ritual, legal, and economic arrangements (e.g., licensure, } \\
\text { quota allocation, hunting seasons, etc.). } \\
\text { Individuals ultimately make decisions to participate or break these } \\
\text { rules (i.e., poaching), in sometimes clear but more-often ambiguous } \\
\text { cultural contexts.' If the consumer is aware of risks, willingness also } \\
\text { reflects risk acceptance or risk aversion. }\end{array}$ & $\begin{array}{l}\text { - You mentioned that vessels don't share } \\
\text { observations of sea and weather conditions. Why } \\
\text { is this? } \\
\text { - What would you have done for food if you didn't } \\
\text { get a moose this season? }\end{array}$ \\
\hline
\end{tabular}

${ }^{1}$ Poaching is a difficult topic to broach in such interviews, and as such we did not address it specifically except with participants that we know well. At best, the topic is hinted at or spoken of as something that other people may have to do.

Most hunting occurs primarily during the open season in fall. There are also various types of permit hunts, assigned by draw or through registration, for winter hunting, for cow hunting, and for areas where demand is deemed higher than a moose population can sustain. Permit hunts may be restricted to state residents, and can involve an application process in which subsistence need must be demonstrated. With a few exceptions for emergencies, traditional uses, and hunting by proxy, the regulated limit is one moose per person each year. Though one moose is not enough to feed even a small family for a year, sharing and trading are common, and a single moose often goes into the smokehouses and freezers of several families. An average harvest of 7055 moose has been reported in Alaska each year from 2002 to 2007, and this number provides a rough estimate of 2000 tons of meat (ADF\&G, 2009b).

Managers of the subsistence harvest must navigate a difficult landscape, as state and federal jurisdictions have created a complex mosaic of rules and regulations (Caulfield, 1992; Huntington, 1992). On federal lands, subsistence hunting and fishing might be managed by the U.S. Department of Fish and Wildlife (USFWS) or the National Park Service (NPS). On state lands, which we focus on here, hunting activities are managed by the Alaska Department of Fish and Game (ADF\&G) in accordance with regulations established by the state Board of Game (BoG) and with a mandate for "intensive management," which describes the goal of not just maximizing but increasing sustainable yield (T. Paragi, ADF\&G, pers. comm. 2010). Some privately held lands are also productive hunting and fishing areas. Jurisdictional authority can be unclear with respect to regulation and enforcement, and the fact that other state and federal agencies such as the Alaska State Department of Transportation (DOT) and the U.S. Coast Guard (USCG) play enforcement roles with respect to boating and boating safety makes the jurisdictional tangle even more complex.

The BoG is a political body of officials appointed by Alaska's governor and confirmed by state legislators. The BoG (2009) meets two to three times a year from November to April to consider proposals for regulation changes. Formal proposals for regulation changes must be submitted to the BoG in advance of each meeting and may refer only to agenda items and calls for proposals set forth by the BoG at the previous meeting (ADF\&G, 2011). Furthermore, each $\mathrm{BoG}$ meeting addresses issues not for the entire state, but only for a subset of regions, on a rotating, two-year cycle for each region (BoG, 2009). The proposal process is the same for $\mathrm{ADF} \& \mathrm{G}$ biologists and for local community members. It 
is a formal process, requiring official forms and knowledge of existing codes and regulations, and it involves obtaining public comment and testimony. Any individual can submit a proposal; to facilitate this process for communities, 81 local advisory committees were created, although funding for these committees can be an issue (T. Paragi, ADF\&G, pers comm. 2010). Proposals may not be anonymous.

\section{Climatic and Environmental Challenges in the Alaska Interior}

Regional climatic and environmental changes are already having a notable, though unpredictable and often non-linear effect on subsistence activities, through changes in hydrology, seasonality and phenology, land cover, and fish and wildlife abundance and distributions (Nuttall et al., 2004; Rattenbury, 2006; White et al., 2007; McNeeley, 2009). Despite the broad-scale directional trends projected for warming and drying in the region (Chapin et al., 2006), the down-scale impacts of climatic change are being experienced not directionally, but in terms of greater interannual and interseasonal variability (McNeeley, 2009; Wendler and Shulski, 2009). Uncertainty is high regarding how seasonal conditions will play out in the future (Lawler et al., 2010). The timing of the seasons, for instance, including fall freeze-up and spring breakup, are shifting in unpredictable ways from year to year (G. Juday, pers. comm. 2008). River ice conditions are also changing: winter ice is thinner and less predictable, and variability in precipitation and snow pack will affect water levels in both the fall and spring (Euskirchen et al., 2007; Mills et al., 2008; Wendler and Shulski, 2009).

Climatic and environmental changes can affect the distribution and behavior of moose and other wild species through changes to forage distribution and availability, river conditions such as water levels, and weather conditions such as temperature, precipitation, and wind speed and direction (Vivas and Saether, 1987; Van Ballenberghe and Miquelle, 1993; Adams and Dale, 1998). These changes also directly influence hunting activities, including transportation across the landscape, and cause concerns about the spoilage and storage of meat. High water levels, fire, and permafrost thaw slumps are all examples of recent changes that have raised safety concerns and limited access to traditional harvest areas (Crosby, 2009; Loring and Gerlach, 2009). As ecosystems and seasonal patterns change, the environmental cues that hunters use to predict the weather and location of animals can also become less reliable (Krupnik and Jolly, 2002; McNeeley, 2009). The story used to introduce this paper gives an example: some of Patrick's many usual hunting sites - small lakes or marshy areas that he had been visiting for many years - were too flooded, and except for the animal we helped pull from the water, we did not encounter a single moose that day.

Conditions for moose hunting are closest to ideal when brush and other ground cover are thinning (making travel across the landscape easier for man and moose), water levels in the river are not too high, pests such as mosquitoes and flies are sparse, and temperatures are cool (roughly $60^{\circ} \mathrm{F}$ or less) so that the meat can be processed and transported without worrying about quick spoilage. These conditions have traditionally tended to converge in the early fall, sometime between late August and mid September, though this timing is becoming less predictable. Ideally, moose should be hunted earlier rather than later in this period, in order to get bulls at their best body condition. Having gained their weight through the summer, bull moose begin to lose weight in September as they enter the rut. Catching a well-fattened moose is essential; it not only makes for good meat, but also provides a thick layer of fat that Alaska Natives use with a number of other wild foods (for instance, in a dish with berries called "Indian ice-cream" and for preparing small game and birds such as the spruce grouse). Getting a moose before the rut is also important because the physiology of the rut affects the quality of the meat. When bulls enter the rut, they begin to "stink": the meat becomes increasingly less palatable, and much care has to be taken during this time to avoid the animal's pungent gland secretions (T. Paragi, ADF\&G, pers. comm. 2009). Some parts of the moose that are normally prized delicacies, such as the liver and kidneys, "turn white" and become entirely inedible during this time because of changes in body chemistry (Franzmann and Leresche, 1978; P. Smith, pers. comm. 2009).

\section{Results of Interviews in the Interior}

Among the 15 people interviewed in the Interior, the most common challenges raised specifically referred to annual and interannual unpredictability of weather, water levels, and fuel cost increases. Water levels that are too low pose a challenge for transportation during the moose hunt and for other subsistence activities. Waters that are too high keep moose out of many traditional hunting areas, forcing hunters to search longer and farther away, thus losing their time and increasing their fuel costs. Some described how the "environmental cues" or "sense makers" they use for reading and predicting changes in the weather now require more observation or tell different things, and many discussed a need for better regional weather and river forecasts during fall and winter hunting, particularly regarding water levels and freeze-up conditions.

Next, respondents expressed dissatisfaction with the timing and duration of the moose-hunting season as set by the BoG. Numerous complex factors determine where and when a hunter is likely to find moose. A majority of those interviewed suggested that hunting seasons for the past few years have been timed inappropriately. In the Interior, open hunting season generally begins and ends in September, lasting two to three weeks. The rationale for this timing is that the season should begin late enough to allow for the best possible hunting conditions (i.e., mild weather) but end just before the onset of the rut, which conventional wisdom holds begins on or near 24 September each year ( $T$. Paragi, ADF\&G, pers comm. 2009; Van Ballenberghe and 
Miquelle, 1993, but see McNeeley, 2009, for some possible exceptions). Yet, many interviewees described occasions when days and weekends with cool weather and other optimum hunting conditions have passed before the open season begins. Two men, one from Fort Yukon and one from Minto, also discussed years when most hunters had to wait until winter to get a moose because of poor conditions in the fall.

A related problem, one raised by all who questioned the timing of the hunting season, was their inability to do anything about it. Public input to the BoG normally passes through the local advisory committees, and proposals for changes must be submitted in advance of the BoG meetings. Respondents pointed out that the BoG meets well before anyone could know about local weather or land and water conditions in the hunting season (e.g., an early onset of cool fall weather). One hunter from Minto said, "if I don't know that it is a good time to hunt until that morning, how does [the Board of Game] know in the springtime?" Some suggested to us that the BoG process reflects a disinterest in local ecological expertise. Others from Fort Yukon and Minto also discussed social and cultural issues that challenge their ability to write and present proposals in the BoG venue. They described feeling "unwelcome," uncomfortable in a "contentious setting," and in need of representation by someone with authority that the board members would recognize. One person interviewed admitted not wanting to submit a proposal because of potential political ramifications and conflicts of interest between representing his community and representing his employer.

In Fort Yukon, where people also rely heavily on salmon throughout the year, subsistence closures in 2009 for chinook salmon (Oncorhynchus tshawytscha) were also mentioned in interviews because people would have to rely more heavily on moose that year to compensate for the lack of fish. However, this solution was identified as problematic because moose populations in the region are very low, averaging 0.23 per square mile in the Fort Yukon area from 1999 to 2007, compared to the average 3.1 per square mile in the Minto Flats area from 2001 to 2006 (Harper, 2008). In Minto, people do not fish for chinook, but one respondent brought up the closure issue, worried that hunters from the Yukon area would now come to the Minto Flats in search of moose.

Safety was also raised as an issue by many of the respondents, with this linked to the unpredictability of the weather, water levels, and landscape as described above. Death by unintentional injury (e.g., drowning, all-terrain vehicle injuries) is common in rural Alaska; in 2008, the death rate was 52.4 per 100000 , compared to a national average of 38.5 (AKDHSS, 2008). The drowning rate, in particular, has been as high as 10 times the national average, and Alaska Native males ages 30-39, the group most likely to be on the land hunting and fishing, have the highest rates within the state (Lincoln et al., 1996). Many of those interviewed believe that the situation will worsen as conditions change and their confidence in their ability to predict the weather and the landscape decreases. Residents of the Alaska Interior also mention that during their limited winter moose hunts, they are having more frequent encounters with thin winter ice, and open water is occurring in places where it is not expected (W. Schneider, pers. comm. 2009). Too much or too little snow also makes overland travel difficult and dangerous, and it is hard on snow machines and other equipment as well (Rattenbury, 2006).

\section{CASE 2: FISHING IN THE BERING SEA AND ALEUTIAN ISLANDS REGION}

The company fishing town of Unalaska, known to many as Dutch Harbor or just "Dutch," is an epicenter of commercial fishing in Alaska. Well known within popular culture worldwide as a result of the reality-based television series Deadliest Catch, Dutch is home base to the largest commercial fishing port in the United States and one of the largest and most productive ground-fish and crab fisheries in the world. Fishing operations range in size from small family vessels (of Alaska Natives and non-Natives) fishing for household and limited market use to large fleet vessels (length $100 \mathrm{~m}$ or more) capable of freezing fish while out on the open water. Overall, these BSAI fishers provide on average nearly $50 \%$ of the U.S. seafood supply (NMFS, 2008), including about one-third of the total U.S. crab catches (Woodby et al., 2005:18). The ground-fish fisheries are the largest enterprise in the BSAI; fish like pollock (Theragra spp.) dominate the state's commercial harvest, with an average of 4.2 billion pounds harvested per year for 1998-2002 (Woodby et al., 2005:4).

Management of the various BSAI commercial fisheries falls to a mix of state and federal agencies and international treaties, resulting in a complex regulatory landscape, with nuanced details regarding jurisdictional authority, total allowable catch (TAC), regular and emergency openings, and geographic restrictions varying significantly from species to species. In general, however, the State of Alaska has fishery management authority for all salmon, herring, and shellfish populations, and the U.S. Federal government, for the majority of ground-fish, except those within three nautical miles of shore. The salmon and Pacific halibut (Hippoglossus stenolepis) fisheries are governed by commissions established by international treaties between the United States and Canada (the Pacific Salmon Treaty of 1985 and the International Pacific Halibut Commission of 1953).

For years, the shellfish and ground-fish fisheries of the BSAI region were managed under what is referred to as "derby-style" fishery management, with short time slots for open fishing (typically 24-48 hours at a time), during which participants race to catch as many pounds of fish as possible within the allocated time (ADF\&G, 2009a). More recently, however, this has changed to a Limited Access Privilege (LAP) system for the majority of the BSAI's commercial fish and shellfish populations, taking such forms 
as cooperatives and Individual Fishing Quotas (IFQs) and Community Development Quotas (CDQs) (Holland and Ginter, 2001; Fina, 2005). This change from derby-style to LAP-style management, called "rationalization," is a process through which so-called "open-access" fisheries become managed under a rights-based system (Fina, 2004), and governments take responsibility for setting and enforcing a variety of conditions over their use. These conditions include, among others, the issuance of IFQs and the creation of gear restrictions. Both the Alaskan halibut and the North Pacific sablefish fisheries were rationalized in 1995, followed by the BSAI crab fishery in 2005 (NOAA, 2008). Under the new systems, fishing seasons are set quite broadly, with 8.5 months for sablefish and 9 months for halibut, for example (NOAA, 2008). The perceived benefits of these changes include increased economic efficiency, improved conservation and stewardship, and as we discuss below, improved safety (Criddle and Macinko, 2000).

\section{Climatic and Environmental Challenges in the Bering Sea and Aleutian Islands Region}

Altered sea ice and weather patterns related to climate change are already creating numerous new environmental challenges for BSAI fishers. Surface and subsurface changes, such as the distribution of seasonal sea-ice cover, the appearance of invasive marine species, and changing water $\mathrm{pH}$ and temperatures can all have potentially dramatic influences on the distribution and abundance of desirable fish (Mikol, 1997; Hannah et al., 2009). Since the 1970s, the Bering Sea has gradually shifted from a primarily cold Arctic marine ecosystem to a subarctic system (Grebmeier et al., 2006); ocean and air temperatures have warmed; and increasingly, there has been little to no sea ice in the southern Bering Sea (NOAA, 2010). Declining sea ice in the northern Bering as well as the Chukchi and Beaufort seas is also well documented (NSIDC, 2009). Marine species composition has shifted in the southern portion of the Bering Sea, with a dramatic increase in walleye pollock (Theragra chalcogramma), some increase in humpback (Megaptera novaeangliae) and fin whales (Balaenoptera physalus), and declines in Greenland halibut (Reinhardtius hippoglossoides), snow crab (Chionoecetes opilio), and fur seal (Callorhinus ursinus) (Newsome et al., 2007; NOAA, 2010). In the northern Bering and Chukchi seas there is also evidence for a decline in productivity and biomass and change in the species composition of the benthos, with impacts to upper trophic levels including sea birds (Schell, 2000; Benson and Trites, 2002; Grebmeier et al., 2006). Recent (2008) offshore surveys of marine fish in the Beaufort Sea also show changes, including range extensions of species such as walleye pollock, Bering flounder (Hippoglossoides robustus), and Pacific cod (Gadus macrocephalus), as well as increases in snow crab size and abundance (Logerwell et al., 2009).

Changes in storminess and weather, as well as human activities, are also creating new problems for commercial fishers. High storm and wave activity can cause mixing of fish sizes and species, decreasing the potential value of the catch and increasing salmon by-catch. The latter is an extremely problematic phenomenon that brings international treaties and issues of sustainability into the regulatory mix (Alverson et al., 1994). Increased shipping activity from foreign waters can contribute to the introduction of invasive species (Arctic Marine Shipping Assessment, 2009). It remains unclear, however, whether a warming climate will increase storm activity, increase the intensity of storms, make storm activity more unpredictable, or all of the above (Atkinson, 2005). Thus, the only certainty regarding the future of environmental conditions in the BSAI, as with the case of Interior Alaska, is uncertainty.

\section{Results of Needs Assessment on the Coast}

Nearly all of those interviewed on the coast began with answers regarding the increased variability of weather and sea conditions, and these topics were eventually touched on by every respondent. No one interviewed, neither those with only one to two years of fishing experience in the region nor those with multiple decades of experience, could confirm a consistent change in storm frequency or intensity. However, there was consensus that weather conditions had become more unpredictable, in the sense that the natural indicators used to predict weather conditions are proving less reliable than in the past. A related matter raised by a majority was an increased need to rely on weather forecasts and information from agencies and other fishers. Most fishers relied primarily on locally provided information heard on VHF radio, and they described weather products available on the Internet as "rudimentary," "impossible to use," or "entirely irrelevant." Most thought that there could be no substitute for local, "on-the-water" observations. They suggested placing cameras and other weather instruments on buoys in strategic locations and mentioned the need to increase communication and sharing of weather observations among fishers.

Many fishers also reported a general trend for pollock populations to track farther north. They told of fishers having to travel past the Pribilof Islands, something that according to many is unprecedented at least since the mid-1980s, if not earlier. Like the hunters of the Interior, these fishers spend more time now searching for fish; those working for large commercial fishing operations suggested this was not much of a problem, but those working on smaller outfits, or familiar with them, noted that even a few more hours of searching could be devastating given the additional cost of fuel, the impact on fish quality of the added time between catch and processing, and the increased exposure on longer trips to inclement weather, especially for the smallest fishing craft $(\sim 15 \mathrm{~m})$.

The problem of fish mixing, both among species and among size-classes within species, was commonly raised, as was the related issue of a decline in the usefulness of sonar and temperature-directed fishing for identifying the best fishing locations. Some respondents said species 
mixing was problematic because of salmon by-catch, discussing how ship captains would have to slow the vessel down (and thus lose their chance to catch the largest pollock) whenever chinook salmon came up in their nets. Others discussed only the problem of catching pollock too small for the filet market, which meant they would receive the lower pay given for fish suitable only for meal.

One topic that we had anticipated, but which was not mentioned by the coastal fishers interviewed, was the impact of changing conditions on safety. When asked directly about safety, respondents noted that with the eight to nine month open seasons replacing the derby-style fishing, they were not particularly worried about impacts of changing weather on their safety, except within the context of possible rapid changes to weather during longer trips, as described above. When questions were asked to follow up on perceptions of the fisheries rationalization, respondents all spoke favorably about impacts on personal safety and economic security. One respondent said, "In the old system, half the time you had to be crazy to go out, and the other half the fish were too small, only good for fish meal." Six respondents, however, suggested that one negative outcome of the rationalization has been a decline in the number of vessel operators working out of Dutch Harbor, and that this has affected the local economy and culture. Alvin Osterback, director of the Port of Dutch Harbor, noted that "there used to be around 270 boats out on the water, and now we're down to 50, many of which operate out of Seattle rather than here." "It used to be that every year we had a ceremonious blessing of the fleet that was a big to-do down by the docks," added Harbormaster John Days, [but] "last year we [just] said a few brief words in the [harbormaster's] office." Some interviewees linked the change in policy to a string of business closures, which included marine suppliers, welders, and restaurants. Many referred to the recent (2009) closing of a local store by the Alaska Commercial Company (ACC), Alaska's largest chain of rural grocery and merchandise stores, after operating there for 50 years.

\section{DISCUSSION}

Embedded within these two cases are a number of points for comparison. People in both regions are experiencing increasingly unpredictable environmental variability. People in both regions are also finding they have to search longer and farther for harvest species, an adaptation with ramifications for both groups, including an increase in overhead and a possible decline in the quality and economic value of their harvest. All respondents stress the importance of high-quality and timely information about weather conditions when making harvest decisions. They also discussed the various scenarios that could result in a harvest that was less than desirable, or even unusable. And all respondents felt the influence of policy on their ability to respond to these challenges and pursue their livelihoods safely and successfully. With respect to this last point, however, the two regions differed significantly in people's views on whether managers and governance frameworks were helping or hindering their ability to adapt effectively to changing conditions (Table 2).

Flexibility in response to environmental variability has long been a key feature of subsistence strategies for Alaska Natives (Binford, 2002:109-143; Loring and Gerlach, 2010). As described above, however, numerous contemporary economic and ecological factors can limit this flexibility. Some limited-registration winter hunts (for example, in the Minto Flats) have helped some hunters by providing more opportunities to adapt to hunting conditions ( $\mathrm{T}$. Seaton, ADF\&G, pers. comm. 2010). To the extent they are able within state law to do so, ADF\&G managers work hard to improve moose populations near rural areas, with the goal of increasing food security (T. Paragi, ADF\&G, pers. comm. 2010). Nevertheless, the "command-andcontrol" governance structure in the Interior, which gives the state bureaucracy much of the authority to decide when, where, and how much people can hunt, more often serves to amplify rather than to mitigate contemporary environmental and economic challenges to the moose harvest.

Hunters trying to cope with the impacts of environmental change find themselves limited to a few paths, none of which are ideal: 1) to hunt in season, which may mean committing more of their resources and risking travel across a potentially unsafe landscape or waterway, when moose may not be available or appropriate for consumption; 2) to break the law by hunting out of season, when travel is safer or moose are more accessible (an option that rural people are not comfortable with, yet do not deny is sometimes a necessity); or 3) not to hunt at all, which necessarily implies a need to rely more heavily on store-bought foods that (if and when available and affordable) are imperfect nutritional and cultural substitutes. The outcome of the first scenario is low to no success in the moose hunt; the outcome of the second is to risk breaking the law and paying a fine; the outcome of the third is to risk diet-related negative health outcomes in the short and long term.

Hunters also find their ability to create new options limited by a management culture that is slow to implement change, and that many feel is exclusionary and at times hostile. Biologists and other agents of ADF\&G experience similar challenges to collaboration; in our experience, they are very open to improved collaboration with local residents, but they are limited by the same set of bureaucratic processes.

The LAP-style governance in the BSAI region, however, allows for a much more decentralized approach to management. By allowing fishers to meet their ground-fish quotas at any time during an extended fishing period, the authorities are saying that they trust fishers and fishing outfits to make most decisions about where and when to hunt in response to daily and weekly environmental variability. As one fisher said, the new management system "allows us to be fishermen, not just deck-hands." Broader responsibilities, such as setting TAC and monitoring salmon by-catch, remain with 
TABLE 2. Comparison of determinants of viability in the context of environmental uncertainty.

\begin{tabular}{|c|c|c|}
\hline Viability factors & Bering Sea and Aleutian Islands region & Interior Alaska \\
\hline Reachability & $\begin{array}{l}\text { - } 8-9 \text { month fishing season creates broad } \\
\text { opportunities to respond to weather and reports of } \\
\text { distribution/abundance of fish } \\
\text { - Must own an individual or community } \\
\text { development quota share in this limited access } \\
\text { privilege system }\end{array}$ & $\begin{array}{l}\text { - Short, fixed openings limit people's ability to legally adjust to } \\
\text { variability in distribution and abundance } \\
\text { - ADF\&G managers work to improve populations in areas near rural } \\
\text { communities through the 'intensive management paradigm' }\end{array}$ \\
\hline Compatibility & $\begin{array}{l}\text { - Long open seasons also allow fishers the choice to } \\
\text { abort trips and fish again if fish are too small } \\
\text { - Dependent on resources (e.g., cost of gasoline and } \\
\text { time for repeated trips }\end{array}$ & $\begin{array}{l}\text { - Conditions are not always ideal for hunting during open season } \\
\text { - Limited registration hunts, including some where subsistence need } \\
\text { must be demonstrated, give some flexibility for hunting in winter if the } \\
\text { fall hunt failed }\end{array}$ \\
\hline Awareness & $\begin{array}{l}\text { - A wide variety of weather forecasts are available } \\
\text { from state and federal institutions } \\
\text { - Information about conditions is shared within but } \\
\text { not always among fishing outfits } \\
\text { - Fishers often have to make short trips to places } \\
\text { that provide indicators of conditions elsewhere }\end{array}$ & $\begin{array}{l}\text { - Traditional cues used to anticipate the weather, landscape conditions, } \\
\text { and the movement of game are proving less reliable } \\
\text { - Access to weather reports is often limited to local radio } \\
\text { - Condition reports of the landscape are shared between hunters, but } \\
\text { information gathering is limited by costs of travel } \\
\text { - State and federal institutions are not necessarily aware of, or able to } \\
\text { respond to changing daily and weekly conditions. }\end{array}$ \\
\hline Willingness & $\begin{array}{l}\text { - Fishing the BSAI is dangerous, but this has been } \\
\text { effectively reduced by policy (reachability) } \\
\text { - Could further be reduced by better information } \\
\text { (awareness) regarding sea conditions, water } \\
\text { temperatures, etc. } \\
\text { - Those without quota shares must fish illegally or } \\
\text { join a cooperative that owns quotas. }\end{array}$ & $\begin{array}{l}\text { - Many face the difficult decision hunting out of season in order to } \\
\text { provide food for their families } \\
\text { - Can also face uncertain and unsafe hunting conditions } \\
\text { - When cash is used to buy replacement foods from the store, these are } \\
\text { less preferred, less nutritious, and often come at the expense of other } \\
\text { needs, including heating fuel. }\end{array}$ \\
\hline
\end{tabular}

governing bodies that have the resources to facilitate a decision-making process that incorporates the best available information and multiple stakeholders. It is worth noting that fishers also have a much more developed support structure in place for legitimizing their role in co-management than hunters in the Interior, including the social, financial, and political capital of their cooperatives, employers, and the industry at large (Criddle and Macinko, 2001; Kitts and Edwards, 2003).

As noted, it is not uncommon in the sustainability science literature to see recommendations for policies that support the kind of flexibility and adaptability that is currently encouraged in the BSAI fishery. However, only rarely do these recommendations move past superficial treatments of adaptability as a "panacea" to provide practical examples of solutions that support effective, place-based responses with outcomes of local health, environmental security, and sustainability (Ostrom et al., 2007; Cundill and Fabricus, 2010). The BSAI case and others like it are therefore valuable examples for developing effective governance arrangements elsewhere. Numerous experiments with the decentralization of power and decision making are occurring in different parts of the world. Other examples include the cooperatives and non-profit fishery trusts in the fisheries of the American Northeast, (e.g., Cape Cod Commercial Hook Fishermen's Association, 2009; Chesapeake Bay Program, 2010; see Pinto da Silva and Kitts, 2006 for a review) and rangeland management coalitions like the Malpai Borderlands group in the southwestern United States and northern Mexico (Sayre, 2006).

In command-and-control approaches, the role of resource users is often limited to the scope of regional advisory councils, infrequent periods for public comment, and grassroots activism (Gould et al., 1996; Pinto da Silva and Kitts, 2006). Decentralized co-management systems function instead by expanding both the roles of the resource users and the context for collaboration between resource users, management agencies, and scientists (Cash et al., 2003). The intent of these collaborative initiatives is not, however, to undermine or replace the role of the state or of science in the governance process (Pomeroy and Berkes, 1997; Guston, 2001); in other words, the approach does not fall victim to the trap of imagining local solutions as necessarily "better" (Born and Purcell, 2006). Rather, the intent is to experiment with governance arrangements through which management authority and local participation can be more appropriately scaled and integrated to better fit contemporary environmental needs and challenges (Fig. 2).

\section{Decentralizing Wild Game Management in Interior Alaska}

Implementing a decentralized approach to managing Alaska's wild game would mean revisiting multiple features of management that currently fragment hunters' abilities to respond effectively to change. These include the appropriateness of restrictive open-hunting and registration-based hunting seasons and both the design and the culture of collaboration that currently undermine community participation. The assumption inherent in the current approach to moose management is that there is a direct, positive relationship between hunting pressure and the length of the open season. However, a variety of cases provide evidence that local resource users often have significant advantages over centralized management structures when it comes to 


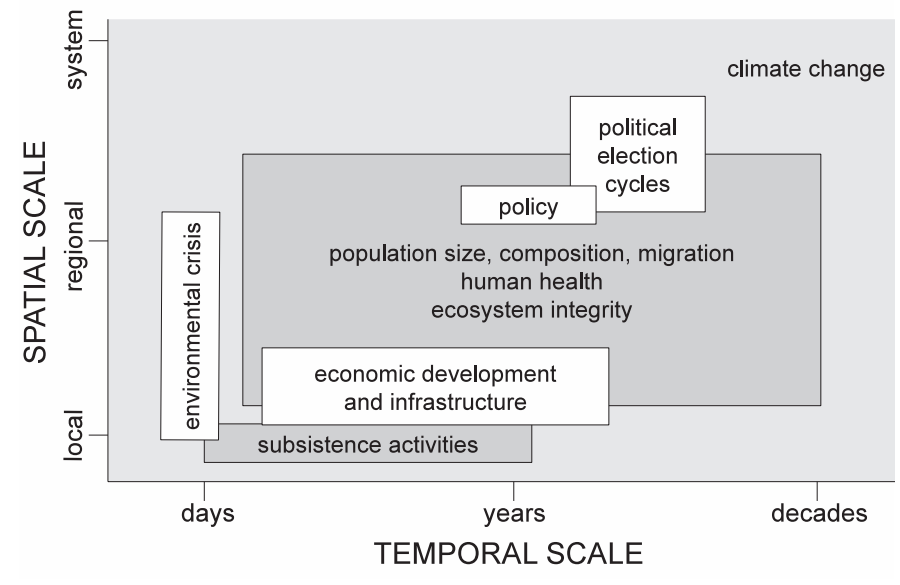

FIG. 2. Scales of various types of human-environment interactions in the context of climatic and environmental change. Note that policy makers and subsistence hunters are situated in very different spatial and temporal contexts. Based on Loring (2010:133) and Vörösmarty et al. (2010:37).

making conservation-minded decisions regarding common property resources, especially in a context of environmental change (Solberg and Sæther, 1999; Cinner and Aswani, 2007; Orlove et al., 2010). Moose hunters in Norway have been shown to have great capacity for monitoring moose populations and for incorporating this information into effective, conservation- and subsistence-based resource management decisions (Solberg and Sæther, 1999). Creating a governance system in Alaska that expands the role of hunters in deciding where, when, and how much to hunt would arguably increase the success of subsistence-based livelihoods, while also bringing significant local ecological expertise to bear on conservation and sustainability priorities.

In the BSAI, the decision-making authority of fishers was expanded through fishery rationalization. A similar privatization of wild game in Alaska would probably be considered undesirable by some, and might even be framed as a violation of the "equal access" provision of the state's constitution (see Caulfield, 1992). In addition, a variety of potential negative social impacts of rationalization, in the BSAI and elsewhere, have yet to be fully assessed or even understood (Anderson, 1995; McCay, 1995; Mansfield, 2007). However, as Pinto da Silva and Kitts (2006) show, decentralized management does not require complete privatization of the resource, but rather involves: 1) the establishment of a social contract for harvest privilege that addresses such details as eligibility, duration, and degree of revocability; 2) some form of self-organization on the part of the resource users; and 3) a collaborative system of data collection and research. In addition to examples of individual quota systems, Pinto da Silva and Kitts (2006) also provide good examples of harvest cooperatives, so-called "gentlemen's agreements," fisheries trusts, and community-based management initiatives, types with quite different configurations. They differ in how resource users self-organize, and how the privilege of harvest is defined, delegated, shared, or revoked when conditions warrant.
For Alaska, decentralizing management for moose involves attaching some degree of management responsibility to the privilege of hunting - for instance, accurate reporting of harvests and indicators of abundance, and the possibility of losing some or all of that privilege for wasteful or unsustainable practices - in return for loosening restrictions on where and when people can hunt. The hunters' vested interest would ideally encourage effective self-policing and social enforcement of sustainable practices, while also increasing the quality and resolution of data available regarding moose populations (Cohn, 2008). Expanded collaboration would also go far toward creating more productive relationships between resource users and federal and state agency representatives (Gilden and Conway, 2002; Shackeroff and Campbell, 2007). No resource management arrangement, however well designed, will lead to successful outcomes if all stakeholders do not feel that there is legitimacy to the role they play (Turner et al., 2008). It is clear from our interviews that many hunters in rural Alaska feel entirely irrelevant to and excluded from the existing management regime: although they do try to participate through venues provided to them by the BoG, they cannot effect any significant change through that participation. A more formal role would increase their desire to participate and might well open the door to the development of more sophisticated local or regional coalitions among stakeholders. Whatever governance structure is ultimately developed should allow room for a range of possible collaborative arrangements to emerge via experimentation by hunters with different forms of self-organization (Pinto da Silva and Kitts, 2006). This flexibility will help emerging arrangements to be as tailored to local and place-based cultural and ecological circumstances as possible.

For local participation to be effective, people need not only the motivation and authority to act, but also access to timely, high-quality information and institutional support for those actions (Deitz et al., 2003; Cinner et al, 2009). Hunters and fishers employ a wide variety of monitoring and forecasting techniques to meet their goals. People on the coast, as well as those in Interior Alaska, frequently stressed their need for improved forecasting in several domains: weather, seascape conditions such as surface currents and subsurface water temperature, sea and river ice conditions, and forecasted timing of seasonal changes such as breakup and freeze-up. Improvements and innovations in these and other "pre-season" forecasting products could go far in helping end-users to make decisions about where and when to hunt or fish.

Many fishers in the BSAI reported the need to make daylong trips just to check the weather at particular "indicator" locations that reveal for them something about fishing conditions elsewhere. In the Interior, regional weekly forecasting of river conditions and wildlife activity could support both increased harvest success in the short term and also longer-term knowledge of the future of Alaska's terrestrial ecosystems. In a new regime, hunters effectively serve not just as resource users, but also as a network of resource 
observers collecting data. Management agencies must learn to play the roles of facilitator and information clearinghouse, while still serving to secure the resource base at an ecosystem level as required by law and best-management practice. Direct collaboration with hunters in the design of these services will be crucial and likely represents a fine starting-point for strengthening effective cross-cultural relationships and trust between user groups and managing agencies (Kendrick, 2003).

As with the fisheries rationalization in the BSAI, however, the implementation of a decentralized system would be a significant undertaking, with numerous administrative challenges (Fina, 2005). As noted above, any move in the direction of a rights-based system would likely evoke much public debate. The impacts on regulation and additional requirements for enforcement could be an area of either concern or opportunity, as many hunters are dissatisfied with the length and complexity of existing regulations. Close monitoring of the short- and long-term environmental impacts of changes in management and harvest practices would also be an important priority (Fina, 2005). An example would be monitoring changes to demographic structure or population dynamics that might introduce vulnerabilities (c.f., Hughes, 2008). In addition to the tasks of securing and monitoring the resource base, creating an equitable, rightsbased management program would require much attention to difficult and contentious details, such as the differential geographic distribution of resources and needs, and the creation of administrative mechanisms for the arbitration of disputes (Hughes, 2008:313).

\section{CONCLUDING REMARKS}

Alaska, a place experiencing some of the most pronounced climate-induced environmental changes in the world, provides an interesting stage for careful, reflexive attention to which aspects of natural resource governance, management, and enforcement enhance people's abilities to respond effectively to environmental variability and change, and which ones do not. Cross-regional comparisons like that of the two cases discussed here, facilitated by the concepts and language of the SOA, provide a way to focus in on the drivers and determinants of path dependence and agency in two largely disparate systems, and to extract useful guidance about how governance can allow a collaborative process that supports community health and environmental security. And, given that the circumpolar North has been identified as an important bellwether of climate change impacts for the rest of the world (Overpeck et al., 2005), the lessons learned here have obvious portability to similar climate change-related issues of resource governance and environmental justice worldwide.

Collaboration as a design principle for environmental policy that supports effective responses to change is broadly discussed, but often only in the most general terms. We hope to have contributed to this discussion by identifying specific recommendations on how to decentralize decision making for the effective and sustainable co-management of wild fish and game. The current command-and-control governance arrangement for natural resource management in Interior Alaska acknowledges little to no ability for stewardship in the users themselves and therefore leaves federal and state agency managers to deal with issues that their bureaucracies are simply not situated to handle. Meanwhile, local people repeatedly demonstrate the capacity, intelligence, expertise, ethic, and desire to collaborate for the stewardship of the resources on which they base their livelihoods.

Elsewhere, it has often taken a crisis or disaster to create opportunities for radical change in governance (Pinto da Silva and Kitts, 2006), and the paradigm of choice with respect to crisis and disaster in the past has often been mitigation rather than the application of precaution and adaptation (Sandin, 1999). We argue here for collaborative planning and anticipation as a preferred alternative for future resource management scenarios (c.f., Glantz, 2001). Some have already characterized rural Alaska as in crisis or even disaster (see Fazzino and Loring, 2009 for a discussion); a challenge for Alaskans will be to mobilize the political capital to move governance and management in a new direction without having to wait for things to get even worse.

\section{ACKNOWLEDGEMENTS}

Support was provided by the Social Vulnerability to Climate Change of Alaska's Coastal Communities Project, (NOAA project NA06OAR4600179), the Alaska Center for Climate Assessment and Policy (ACCAP, a NOAA RISA center), and the Resilience and Adaptation Program at the University of Alaska Fairbanks, an NSF-IGERT (0114423). Thank you to Tom Paragi, Tom Seaton, Reid Brewer, Pete Henrickson, Alvin Osterback, John Days, Darryl Thompson, Patrick Smith, Ben Stevens, Bruce Thomas, Craig Fleener, and others in Dutch, Togiak, Minto, and Fort Yukon who have been more than willing over the years to share their time so that we could better design our research agenda to suit local needs.

\section{REFERENCES}

ACIA. 2005. Arctic climate impact assessment: Scientific report. Cambridge: Cambridge University Press.

Adams, L.G., and Dale, B.W. 1998. Timing and synchrony of parturition in Alaskan caribou. Journal of Mammalogy 79:287-294.

ADF\&G (Alaska Department of Fish and Game). 2009a. Sustaining Alaska's fisheries: Fifty years of statehood.

2009b. Alaska wildlife harvest summary 2005-2006. http://www.wildlife.alaska.gov/pubs/techpubs/mgt_rpts/ harvest_summary.pdf. 
2011. Alaska hunting, trapping \& miscellaneous regulations. http://www.wildlife.alaska.gov/index.cfm?adfg= regulations.main.

AKDHSS (Alaska Department of Health and Social Services). 2008. Death data and statistics. Juneau: AKDHSS. http://www. hss.state.ak.us/dph/infocenter/topics/deaths.htm.

Alaska Department of Commerce, Community, and Economic Development. 2007. Alaska Community database online. http://www.commerce.state.ak.us/dca/commdb/CF_BLOCK. cfm.

Alessa, L., Kliskey, A., Busey, R., Hinzman, L., and White, D. 2008. Freshwater vulnerabilities and resilience on the Seward Peninsula: Integrating multiple dimensions of landscape change. Global Environmental Change 18:256-270, doi:10.1016/j.gloenvcha.2008.01.004.

Allison, H.E., and Hobbs, R.J. 2004. Resilience, adaptive capacity, and the "lock-in trap" of the Western Australian Agricultural Region. Ecology and Society 9:3-27.

Alverson, D.L., Freeberg, M.H., Murawski, S.A., and Pope, J.G. 1994. A global assessment of fisheries bycatch and discards. FAO Fisheries Technical Paper 339. Geneva, Swizerland: Food and Agriculture Organization.

Anderson, L.G. 1995. A commentary on the views of environmental groups on access control in fisheries. Ocean \& Coastal Management 28:165-188, doi:10.1016/0964-5691(96)00001-4.

Arctic Marine Shipping Assessment. 2009. AMSA 2009 Report. Tromsø, Norway: Protection of the Arctic Marine Environment Working Group (PAME), Arctic Council.

Armitage, D.R., Berkes, F., and Doubleday, N. 2007. Adaptive co-management: Collaboration, learning, and multi-level governance. Vancouver: UBC Press.

Armitage, D.R., Plummer, R., Berkes, F., Arthur, R.I., Charles, A.T., Davidson-Hunt, I.J., Diduck, A.P., et al. 2009. Adaptive co-management for social-ecological complexity. Frontiers in Ecology and the Environment 7:95-102, doi:10.1890/070089.

Atkinson, D.E. 2005. Observed storminess patterns and trends in the circum-Arctic coastal regime. Geo-Marine Letters 25: 98-109, doi:10.1007/s00367-004-0191-0.

Bennett, J. 1976. The ecological transition: Cultural anthropology and human adaptation. New York: Pergamon.

-. 1996. Human ecology as human behavior. New Brunswick: Transaction Publishers.

Benson, A.J., and Trites, A.W. 2002. Ecological effects of regime shifts in the Bering Sea and eastern North Pacific Ocean. Fish and Fisheries 3:95-113, doi:10.1046/j.1467-2979.2002.00078.x.

Binford, L. 2002. In pursuit of the past: Decoding the archaeological record. Berkeley: University of California Press.

Board of Game. 2009. Alaska Dept. of Fish and Game Section of Boards Support: Board of Game. http://www.boards.adfg. state.ak.us/gameinfo/index.php.

Born, B., and Purcell, M. 2006. Avoiding the local trap: Scale and food systems in planning research. Journal of Planning Education and Research 26:195-207, doi: 10.1177/0739456X 06291389.

Cape Cod Commercial Hook Fishermen's Association. 2009. Cape Cod Fisheries Trust: About the program. http://www. ccchfa.org/trust/.
Cash, D.W., Clark, W.C., Alcock, F., Dickson, N.M., Eckley, N., Guston, D.H., Jäger, J., and Mitchell, R.B. 2003. Knowledge systems for sustainable development. Proceedings of the National Academy of Sciences of the United States 100: 8086-8091, doi:10.1073/pnas.1231332100.

Caulfield, R. 1992. Alaska's subsistence management regimes. Polar Record 28:23-32.

Chapin, F.S., III, Lovecraft, A.L., Zavaleta, E.S., Nelson, J., Robards, M.D., Kofinas, G.P., Trainor, S.F., Peterson, G.D., Huntington, H.P., and Naylor, R.L. 2006. Policy strategies to address sustainability of Alaska boreal forests in response to a directionally changing climate. Proceedings of the National Academy of Sciences of the United States 103:16637-16643.

Chesapeake Bay Program. 2010. Oyster management and restoration. http://www.chesapeakebay.net/oystersmanagement. aspx?menuitem $=14770$.

Cinner, J., and Aswani, S. 2007. Integrating customary management into marine conservation. Biological Conservation 140: $201-216$.

Cinner, J., Fuentes, M.M., and Randriamahazo, H. 2009. Exploring social resilience in Madagascar's marine protected areas. Ecology and Society 14:41, http://www.ecologyandsociety.org/ vol14/iss1/art41/.

Cohn, J.P. 2008. Citizen science: Can volunteers do real research? BioScience 58:192, doi:10.1641/B580303.

Costanza, R., Fisher, B., Ali, S., Beer, C., Bond, L., Boumans, R., Danigelis, N.L., et al. 2007. Quality of life: An approach integrating opportunities, human needs, and subjective wellbeing. Ecological Economics 61:267-276, doi:10.1016/j.eco lecon.2006.02.023.

Criddle, K.R., and Macinko, S. 2000. A requiem for the IFQ in US fisheries? Marine Policy 24:461 -469, doi:10.1016/S0308597X(00)00025-7.

. 2001. Political economy and profit maximization in the eastern Bering Sea fishery for walleye pollock. In: Johnston, R.S., ed., and Shriver, A.L., compiler. Proceedings of the Tenth Biennial Conference of the International Institute of Fisheries Economics and Trade, 10-14 July 2000, Corvallis, Oregon, USA. Corvallis: International Institute of Fisheries Economics and Trade (IIFET).

Crosby, B.T. 2009. Progressive growth, modulated supply: How coupling and decoupling between an enormous retrogressive thaw slump and its depositional fan impacts sediment delivery to the Selawik River, Northwest Alaska. Eos Transactions, American Geophysical Union, Fall Meeting 2009, abstract \#U41C-0043.

Cundill, G., and Fabricus, C. 2010. Monitoring the governance dimension of natural resource co-management. Ecology and Society 15:15, http://www.ecologyandsociety.org/vol15/iss1/ $\operatorname{art15/.}$

de Groot, R.S., Wilson, M.A., and Boumans, R.M.J. 2002. A typology for the classification, description and valuation of ecosystem functions, goods and services. Ecological Economics 41:393-408, doi:10.1016/S0921-8009(02)00089-7.

Deitz, T., Ostrom, E., and Stern, P. 2003. The struggle to govern the commons. Science 302:1908-1912. 
Egeland, G.M., Pacey, A., Cao, Z., and Sobol, I. 2010. Food insecurity among Inuit preschoolers: Nunavut Inuit Child Health Survey, 2007-2008. Canadian Medical Association Journal 182:243-248, doi:10.1503/cmaj.091297.

EPA (U.S. Environmental Protection Agency). 2009. The National Environmental Policy Act of 1969. (42 U.S.C.A. § 4331 et seq.)

Euskirchen, E.S., McGuire, A.D., and Chapin, F.S., III. 2007. Energy feedbacks of northern high-latitude ecosystems to the climate system due to reduced snow cover during 20th century warming. Global Change Biology 13:2425-2438, doi:10.1111/ j.1365-2486.2007.01450.x.

Fazzino, D.V., and Loring, P.A. 2009. From crisis to cumulative effects: Food security challenges in Alaska. NAPA Bulletin 32:152 - 177, doi:10.1111/j.1556-4797.2009.01033.x.

Fina, M. 2004. Rights-based management. In: Witherell, D., ed. Proceedings of a Symposium on Fisheries Management in the United States. Juneau, AK: North Pacific Fisheries Management Council.

- 2005. Rationalization of the Bering Sea and Aleutian Islands crab fisheries. Marine Policy 29:311 - 322, doi:10.1016/j. marpol.2004.05.005.

Forbes, B.C., Stammler, F., Kumpula, T., Meschtyb, N., Pajunen, A., and Kaarlejärvi, E. 2009. High resilience in the YamalNenets social-ecological system, West Siberian Arctic, Russia. Proceedings of the National Academy of Sciences of the United States 106:22041-22048, doi:10.1073/pnas.0908286106.

Ford, J.D. 2008. Emerging trends in climate change policy: The role of adaptation. International Public Policy Review 3:5-16.

- 2009. Vulnerability of Inuit food systems to food insecurity as a consequence of climate change: A case study from Igloolik, Nunavut. Regional Environmental Change 9:83-100, doi:10.1007/s10113-008-0060-x.

Franzmann, A.W., and Leresche, R.E. 1978. Alaskan moose blood studies with emphasis on condition evaluation. The Journal of Wildlife Management 42:334-351.

Garud, R., and Karnøe, P., eds. 2001. Path dependence and creation. London: Routledge.

Gilden, J., and Conway, F. 2002. An investment in trust: Communications in the commercial fishing and fisheries management communities. ORESU-G-01-004. Corvallis: Oregon Sea Grant, Oregon State University.

Glantz, M.H. 2001. Once burned, twice shy?: Lessons learned from the 1997-98 El Niño. Tokyo: United Nations University Press.

Goetz, T.C. 2004. Sharing the Canadian experience with comanagement: Ideas, examples and lessons for communities in developing areas. Ottawa: International Development Research Centre.

Goldsmith, S. 2008. Understanding Alaska's remote rural economy. UA Research Summary 10. Anchorage: Institute of Social and Economic Research, University of Alaska Anchorage.

Gould, K.A., Schnaiberg, A., and Weinberg, A.S. 1996. Local environmental struggles: Citizen activism in the treadmill of production. Cambridge: Cambridge University Press.

Grebmeier, J.M., Overland, J.E., Moore, S.E., Farley, E.V., Carmack, E.C., Cooper, L.W., Frey, K.E., Helle, J.H.,
McLaughlin, F.A., and McNutt, S.L. 2006. A major ecosystem shift in the northern Bering Sea. Science 311:1461-1464, doi:10.1126/science.1121365.

Guston, D.H. 2001. Boundary organizations in environmental policy and science: An introduction. Science, Technology \& Human Values 26:399-408, doi:10.1177/016224390102600401.

Guyette, S. 1996. Planning for balanced development: A guide for Native American and rural communities. Santa Fe, New Mexico: Clear Light Books.

Hamilton, L.C., and Seyfrit, C.L. 1994. Female flight? Gender balance and outmigration by Native Alaskan villagers. Arctic Medical Research 53(Suppl. 2):189-193.

Hannah, C.G., Dupont, F., and Dunphy, M. 2009. Polynyas and tidal currents in the Canadian Arctic Archipelago. Arctic 62:83-95.

Harper, P., ed. 2008. Moose management report, 1 July 2005-30 June 2007. Juneau: Alaska Department of Fish and Game, Wildlife Conservation Division.

Holland, D.S., and Ginter, J.C. 2001. Common property institutions in the Alaskan groundfish fisheries. Marine Policy 25:33-42, doi:10.1016/S0308-597X(00)00033-6.

Holthaus, G. 2008. Learning Native wisdom: What traditional cultures teach us about subsistence, sustainability, and spirituality. Lexington: The University Press of Kentucky.

Hughes, T. 2008. Project: Coping with change: Resilience of marine social-ecological systems. Environmental Futures Network, University of Adelaide. http://www.adelaide.edu.au/ efn/projects/wgp/THughes_Project.html\#publication.

Huntington, H.P. 1992. Wildlife management and subsistence hunting in Alaska. Seattle: University of Washington Press.

Kendrick, A. 2003. Caribou co-management in northern Canada: Fostering multiple ways of knowing. In: Berkes, F., Colding, J., and Folke, C., eds. Navigating social-ecological systems: Building resilience for complexity and change. Cambridge: Cambridge University Press. 241-267.

Keskitalo, E.C.H. 2008. Vulnerability and adaptive capacity in forestry in northern Europe: A Swedish case study. Climatic Change 87:219-234, doi:10.1007/s10584-007-9337-1.

Kitts, A.W., and Edwards, S.F. 2003. Cooperatives in US fisheries: Realizing the potential of the fishermen's collective marketing act. Marine Policy 27:357-366, doi:10.1016/S0308597X(03)00050-2.

Kofinas, G.P., Herman, S.J., and Meek, C. 2007. Novel problems require novel solutions: Innovation as an outcome of adaptive co-management. In: Armitage, D.R., Berkes, F., and Doubleday, N., eds. Adaptive co-management: Collaboration, learning, and multi-level governance. Vancouver: University of British Columbia Press. 249-267.

Krupnik, I., and Jolly, D., eds. 2002. The earth is faster now: Indigenous observations of Arctic environmental change. Fairbanks: Arctic Research Consortium of the United States.

Lawler, J.J., Tear, T.H., Pyke, C., Shaw, M.R., Gonzalez, P., Kareiva, P., Hansen, L., et al. 2010. Resource management in a changing and uncertain climate. Frontiers in Ecology and the Environment 8:35-43, doi:10.1890/070146.

Lincoln, J.M., Perkins, R., Melton, F., and Conway, G.A. 1996. Drowning in Alaskan waters. Public Health Reports 111: $531-535$. 
Logerwell, E., Rand, K., Horne, J., Parker-Stetter, S., and Weingartner, T. 2009. Beaufort Sea: What lives there now? What may live there? In: International Arctic Fisheries Symposium 2009, 19-21 October, Anchorage, Alaska.

Loring, P. 2010. Ways to help and ways to hinder: Climate, health and food security, in Alaska. PhD thesis, University of Alaska Fairbanks, Fairbanks, Alaska.

Loring, P.A., Chapin, F.S., and Gerlach, S.C. 2008. Servicesoriented architecture: Ecosystem Services as a framework for diagnosing change in social ecological systems. Ecosystems 113:478-489, doi:10.1007/s10021-008-9136-1.

Loring, P.A, and Gerlach, S.C. 2009. Food, culture, and human health in Alaska: An integrative health approach to food security. Environmental Science \& Policy 12:466-478, doi: 10.1016/j.envsci.2008.10.006.

. 2010. Outpost gardening in interior Alaska: Food system innovation and the Alaska Native gardens of the 1930s through the 1970s. Ethnohistory 57:183-199, doi:10.1215/001418012009-060.

Lynch, A.H., and Brunner, R.D. 2007. Context and climate change: An integrated assessment for Barrow, Alaska. Climatic Change 82:93 - 111, doi:10.1007/s10584-006-9165-8.

Mansfield, B. 2007. Property, markets, and dispossession: The Western Alaska Community Development Quota as neoliberalism, social justice, both, and neither. Antipode 39:479-499, doi:10.1111/j.1467-8330.2007.00536.x.

Mayr, E. 1982. The growth of biological thought: Diversity, evolution, and inheritance. Cambridge, Massachusetts: Harvard University Press.

Mazess, R. 1975. Adaptation: A conceptual framework. In: Meier, R.J., Otten, C.M., and Abdel-Hameed, F., eds. Evolutionary models and studies in human diversity. The Hague: Mouton Press. 9-15.

McCay, B.J. 1995. Social and ecological implications of ITQs: An overview. Ocean \& Coastal Management 28:3-22.

McNeeley, S.M. 2009. Seasons out of balance: Climate change impacts, vulnerability, and sustainable adaptation in interior Alaska. PhD thesis, University of Alaska Fairbanks.

Mikol, B. 1997. Temperature directed fishing: How to reduce bycatch and increase productivity. Marine Advisory Bulletin 48. Fairbanks: Alaska Sea Grant College Program.

Mills, J., Rosenberger, A., Daum, D., and Solie, D. 2008. EPSCoR climate change research: Examination of long-term ice breakup and freeze-up trends in the Yukon River based on historical data sources collected for the Yukon River Temperature Archive Project. In: Duffy, L.K., ed. Growing sustainability science in the North. Abstracts of papers presented at the AAAS Arctic Science Conference, 15-17 September 2008, Fairbanks, Alaska. 41.

Moran, E.F. 1979. Human adaptability: An introduction to ecological anthropology. North Scituate, Massachusetts: Duxbury Press.

1981. Human adaptation to Arctic zones. Annual Reviews of Anthropology 10:1-25.

Newsome, S.D., Etnier, M.A., Kurle, C.M., Waldbauer, J.R., Chamberlain, C.P., and Koch, P.L. 2007. Historic decline in primary productivity in western Gulf of Alaska and eastern
Bering Sea: Isotopic analysis of northern fur seal teeth. Marine Ecology Progress Series 332:211-224, doi:10.3354/ meps332211.

NMFS (National Marine Fisheries Service). 2008. Fisheries of the United States. Silver Springs, Maryland: NMFS, Office of Science and Technology.

NOAA (National Oceanic and Atmospheric Administration). 2008. BSAI crab rationalization FAQ. http://www.fakr.noaa. gov/sustainablefisheries/crab/rat/progfaq.htm\#wicr.

_ 2010. Bering Climate and Ecosystem - Bering Sea status and overview. http://www.beringclimate.noaa.gov/bering status_overview.html.

NSIDC (National Snow and Ice Data Center). 2009. Arctic sea ice extent remains low: 2009 sees third lowest mark. NSIDC Press Room, October 6. http://nsidc.org/news/press/20091005_ minimumpr.html.

Nuttall, M., Berkes, F., Forbes, B., Kofinas, G., Vlassova, T., and Wenzel, G. 2004. Hunting, herding, fishing, and gathering: Indigenous peoples and renewable resource use in the Arctic. In: Arctic Climate Impact Assessment: Scientific report. Cambridge: Cambridge University Press. 649-690.

Orlove, B., Roncoli, C., Kabugo, M., and Majugu, A. 2010. Indigenous climate knowledge in southern Uganda: The multiple components of a dynamic regional system. Climatic Change 100:243-265, doi:10.1007/s10584-009-9586-2.

Ostrom, E. 2007. A diagnostic approach for going beyond panaceas. Proceedings of the National Academy of Sciences of the United States 104:15181-15187, doi:10.1073/pnas.0702288104.

- 2009. A general framework for analyzing sustainability of social-ecological systems. Science 325:419-422, doi:10.1126/ science.1172133.

Ostrom, E., Janssen, M.A., and Anderies, J.M. 2007. Going beyond panaceas. Proceedings of the National Academy of Sciences of the United States 104:15176-15178, doi:10.1073/ pnas.0701886104.

Overpeck, J.T., Sturm, M., Francis, J.A., Perovich, D.K., Serreze, M.C., Benner, R., Carmack, E.C., et al. 2005. Arctic system on trajectory to new, seasonally ice-free state. EOS 86:309-313, doi:10.1029/2005EO340001.

Pinto da Silva, P., and Kitts, A. 2006. Collaborative fisheries management in the Northeast US: Emerging initiatives and future directions. Marine Policy 30:832-841, doi:10.1016/j. marpol.2006.04.003.

Pomeroy, R.S., and Berkes, F. 1997. Two to tango: The role of government in fisheries co-management. Marine Policy 21:465 - 480, doi:10.1016/S0308-597X(97)00017-1.

Pomeroy, R.S., and Rivera-Guieb, R. 2005. Fishery co-management: A practical handbook. Oxford: CABI Publishing. http:// www.idrc.ca/openebooks/184-1/.

Pomeroy, R.S., Ratner, B.D., Hall, S.J., Pimoljinda, J., and Vivekanandan, V. 2006. Coping with disaster: Rehabilitating coastal livelihoods and communities. Marine Policy 30: $786-793$.

Rattenbury, K.L. 2006. Reindeer herding, weather, and environmental change on the Seward Peninsula, Alaska. MS thesis, Department of Biology and Wildlife, University of Alaska Fairbanks. 
Sandin, P. 1999. Dimensions of the precautionary principle. Human and Ecological Risk Assessment: An International Journal 5:889-907, doi:10.1080/10807039991289185.

Sayre, N. 2006. Working wilderness: The Malpai Borderlands Group Story and the future of the Western Range. Tucson: Rio Nuevo Publishers.

Schell, D.M. 2000. Declining carrying capacity in the Bering Sea: Isotopic evidence from whale baleen. Limnology and Oceanography 45:459-462.

Shackeroff, J.M., and Campbell, L.M. 2007. Traditional ecological knowledge in conservation research: Problems and prospects for their constructive engagement. Conservation and Society 5:343-360.

Solberg, E.J., and Sæther, B.-E. 1999. Hunter observations of moose Alces alces as a management tool. Wildlife Biology 5:107-117.

Turner, N.J., Gregory, R., Brooks, C., Failing, L., and Satterfield, T. 2008. From invisibility to transparency: Identifying the implications. Ecology and Society 13:7, http://www. ecologyandsociety.org/vol13/iss2/art7/.

Van Ballenberghe, V., and Miquelle, D.G. 1993. Mating in moose: Timing, behavior, and male access patterns. Canadian Journal of Zoology 71:1687-1690.

Vivas, H., and Sæther, B. 1987. Interactions between a generalist herbivore, the moose Alces alces, and its food resources: An experimental study of winter foraging behaviour in relation to browse availability. Journal of Animal Ecology 56:509-520.
Vörösmarty, C.J., McGuire, A.D., and Hobbie, J.E., eds. 2010. Scaling studies in Arctic system science and policy support: A call-to-research. Washington D.C.: U.S. Arctic Research Commission. www.arctic.gov/publications/arctic_scaling.pdf.

Walker, B., Holling, C.S., Carpenter, S.R., and Kinzig, A. 2004. Resilience, adaptability and transformability in socialecological systems. Ecology and Society 9:5, http://www. ecologyandsociety.org/vol9/iss2/art5/.

Wendler, G., and Shulski, M. 2009. A century of climate change for Fairbanks, Alaska. Arctic 62:295-300.

Wheeler, P. 1998. The role of cash in northern economies: A case study of four Alaskan Athabaskan villages. PhD thesis, University of Alberta, Edmonton.

White, D.M., Gerlach, S.C., Loring, P., Tidwell, A., and Chambers, M.C. 2007. Food and water security in a changing Arctic climate. Environmental Research Letters 2:4, doi:10.1088/17489326/2/4/045018.

Wolfe, R.J. 2004. Local traditions and subsistence: A synopsis from twenty-five years of research by the State of Alaska. Technical Paper 284. Juneau: Alaska Department of Fish and Game, Division of Subsistence

Woodby, D., Carlile, D., Siddeek, S., Funk, F., Clark, J.H., and Hulbert, L. 2005. Commerical fisheries of Alaska. Special Publication 05-09. Juneau: Alaska Department of Fish and Game, Division of Sport Fish and Commercial Fisheries.

Young, O.R. 2002. The institutional dimensions of environmental change: Fit, interplay, and scale. Cambridge, Massachusetts: The MIT Press. 